\title{
A STUDY ABOUT THE HEALTH REFERENCE INFORMATION SYSTEM IN THE CASE OF NON SPECIALISTICS IN KENDARI CITY PRIMARY HEALTH CARE
}

\author{
Sartini Risky ${ }^{1}$, Abdul Azis Harun ${ }^{2}$, Anry Hariadhin Depu ${ }^{3}$ \\ ${ }^{1,2,3}$ Universitas Mandala Waluya, in Kendari Southeast Sulawesi Province, Indonesia \\ Corresponding Author : Sartini Risky \\ Email : risky.sarjan87@gmail.com
}

\section{Abstract}

Background: I Implementation of a reference information system will not work well when its implementation is not in accordance with the policy or guidelines. One of the problems in implementing the referral system is the health information system, in this case the referral guidelines and referral templates.

Methods: This research uses qualitative method and it conducted the Kendari City Inpatient Primary health care form April 2020 to August 2020. The informants in the study were the Kendari branch of the health insurance officers, consisting of the Head of the Inpatient Community Health Center, the doctors of Inpatient Primary health care, the Head of Primary Benefit Guarantee and 4 referral patients in the Inpatient Primary health care. Data analysis of interview data used a NVIVO QSR application 12.

Results: There is a conceptual linkage between the Reference Guidelines, Referral Procedures, and Reference Patterns with the concept of implementing the referral system

Conclusion: There is a conceptual linkage between the Reference Guidelines, Referral Procedures, and Reference Patterns with the concept of implementing the referral system.

Key words: Referral, Guidelines, Procedures, Patterns, Information, Systems 


\section{INTRODUCTION}

Health is one of the things of global concern in order to improve the development of a country. Therefore, development in the health sector is very important. To realize global commitments as mandated by the 58th World Health Assembly (WHA) resolution 2005 in Geneva which wants health financing systems in many countries to be further developed to ensure access to the services needed while providing protection against financial risks through the National Health Insurance program $(\mathrm{JKN})(1)$.

The goverment Indonesia made serious efforts to develop health insurance by issuing legal protection from Law no. $40 / 2004$ on the issue of the National Social Security System (SJSN).(2) On January 1, 2014, the Social Security Administering Body for Health was established, BPJS Kesehatan as the Implementing Body is a public legal entity established to administer health insurance programs for all Indonesians(3).

In the JKN Era, First Level Health Facilities became the vanguard in the health service system. So that demands for excellent service facilities are important for FKTPs. One type of first level health service facility is the Community Health Center . Primary health care is a health service facility that organizes public health efforts and first-level individual health efforts, by prioritizing promotive and preventive efforts, to achieve the highest public health status in its working area.(4).

Based on the Rancid Regulation of the Minister of Health of the Republic of Indonesia Number 1 of 2012 concerning Individual Health Service Referral Systems explains that the referral system is a health service delivery that regulates the transfer of duties and responsibilities of health services both vertically and horizontally. Health services are implemented in stages, according to medical needs starting from the first level of health services(5).
PermaReference errors in Southeast Sulawesi are still quite complex. Based on preliminary preliminary studies conducted by researchers at several health centers, it was found that there were several problems related to human resources, time, services and costs, facilities and infrastructure. The basic thing that was found was a lack of understanding of health workers regarding the referral system guidelines as well as an understanding of the 144 diagnoses that became the competence of doctors. Kendari City is a city in Southeast Sulawesi which consists of 15 health centers. From the referral figures in Southeast Sulawesi, this area has a fairly high referral rate at the Primary health care Nursing for nonspecialized cases compared to other districts, namely 130 referrals for Kendari City.(6).

The referral rate at the care Primary health care for non-specialized cases in Kendari city has increased cases, namely in 2016 as many as 9 cases then increased in 2017 by 25 cases, and in 2018 it continued to increase, namely 130 non-specialized referral cases (BPJS Kesehatan Kendari Branch, 2019) . In addition to the reference figures above, the basis for the researchers to take the area, namely that for Kendari City as the representative of the mainland areas in Southeast Sulawesi and for the utilization of health services, it is more than the rural areas.(7).

Implementation of a system will not work well if its implementation is not in accordance with the provisions of the policy or guidelines. One of the problems in implementing the referral system is the health information system, in this case the referral guidelines and referral templates. This is in line with research conducted by Doaly in 2016 which found several problems in the implementation of the system at Dr. Sam Ratulangi Tondano's referrals include a referral form that was not filled in by the doctor at the hospital, a return referral form was not returned to the doctor at the FKTP, the doctor's writing was 
not readable by the doctor at the FKTP, human resources (expert doctor, X-ray administrators) did not stay in the hospital, so cases that could have been handled in the hospital were referred, (8).

Based on the description above, it is necessary to make efforts in structuring an effective and structured referral system, so it is necessary to conduct a study to examine the health referral information system in non-specialized cases in Kendari City Health Center.

\section{METHOD}

The method in this research is qualitative. Implemented at the Kendari City Inpatient Health care in April 2020 until finished. The informants in the study were the Kendari branch of the health insurance office consisting of the Head of Inpatient Community Health Centers, Inpatient Health care Doctors, the Head of Primary Benefit Guarantee (PMP) and 4 referral patients at the Inpatient Health care. Data collection was collected through out documentation, behavioral observation, or interviews with participants / informants. Data analysis of interview data using the QSR NVIVO 12 application.

\section{RESULTS}

Image 1 shows the relationship between the reference guide and the concept of implementing the referral system has a conceptual linkage. This can be seen from several indicators of reference guidelines, namely 25 information that states the linkage between the available reference applications and the implementation of the referral system, 21 information that states the relationship between the concept of conformity of rules to the implementation of the referral system, there are 33 information that states the relationship between the concept of document availability. on the implementation of the referral system and there are 33 information that states the relationship between the concept of regionalization and the implementation of the referral system.

Figure 2 explains about the linkage between the referral procedure and the concept of implementing the referral system has a conceptual linkage. This can be seen from several indicators of referral procedures, namely 21 information that states the relationship between the concept of the referral mechanism and the implementation of the referral system, and 21 information that states the relationship between the concept of initial action before referring to the implementation of the referral system.

Figure 3 shows about the relationship between the reference pattern and the implementation concept of the referral system has a conceptual linkage. This can be seen from several indicators of referral patterns, namely there are 30 information that states the relationship between the concept of request itself to the implementation of the referral system, and there are 21 information that states the relationship between the concept of doctor's attitude towards the implementation of the referral system. 
Risky, S., Harun, A. A., \& Depu, A. H.

DOI: 10.36566/ijhsrd/Vol3.Iss1/79

https://ijhsrd.com/index.php/ijhsrd

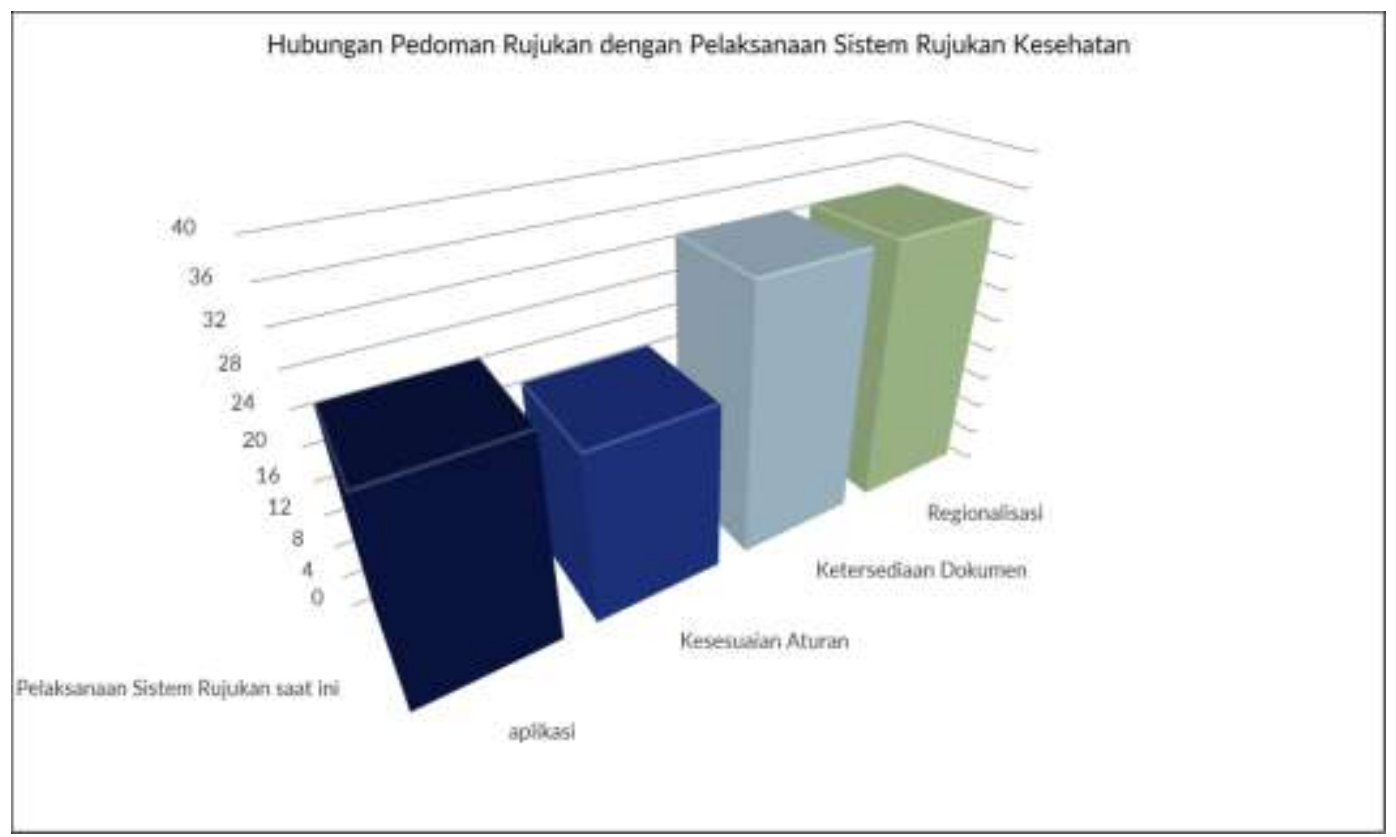

Image 1

Referral Guidelines with the Implementation of the Health Referral System

Hubungan Prosedur Rujukan dengan Pelaksanaan Sistem Rujukan Kesehatan

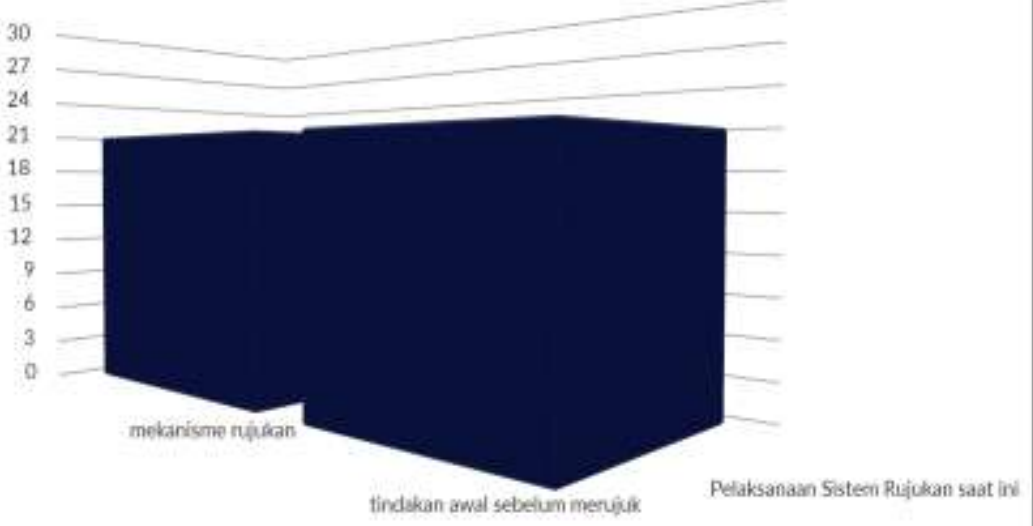

Figure 2

Referral Procedure with Health Referral System Implementation

Indonesian Journal Of Health Sciences Research and Development

Vol. 3, No.1, March 2021 
Risky, S., Harun, A. A., \& Depu, A. H. DOI: 10.36566/ijhsrd/Vol3.Iss1/79 https://ijhsrd.com/index.php/ijhsrd

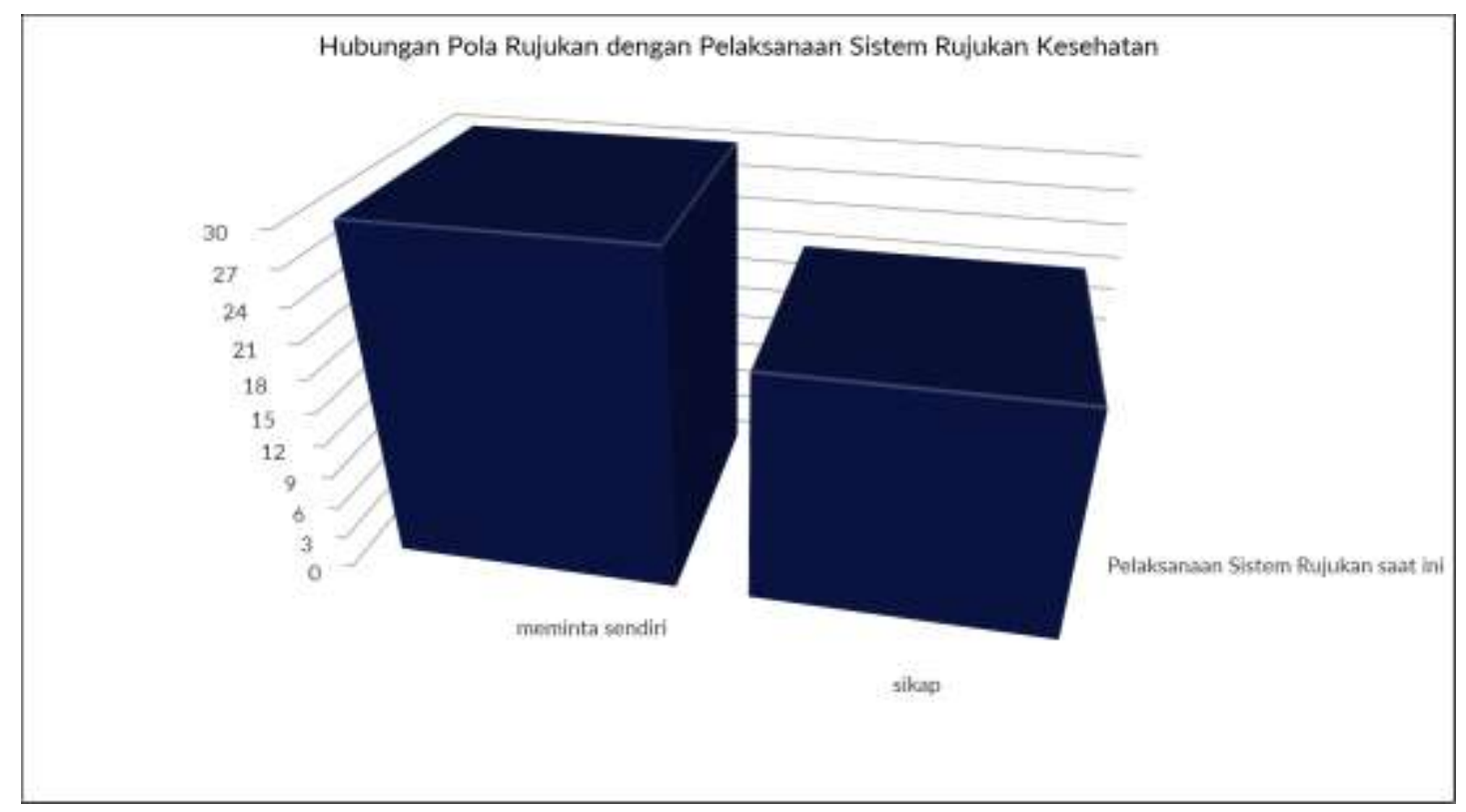

Figure 3

\section{Referral Patterns with the Implementation of the Health Referral System}

\section{DISCUSSION}

\section{Reference Guidelines}

1. Document Availability

From the results of the study, that the BPJS referral system guidelines already exist and are held by all Puskesmas, these guidelines refer to the regulations of the minister of health and presidential regulations which must serve as guidelines for Primary health care in carrying out referrals at Primary health care. With the existence of a referral guideline document, this proves that the implementation of the health referral system at the Primary health care in Kendari City and Bau-Bau City is carried out based on established guidelines.

The referral procedure begins with the community who needs health services and must be carried out by health personnel at the FKTP, in this case the puskesmas. If the Primary health care does not have the ability and authority and the patient needs further health services, the Primary health care is obliged to make a referral. Referral procedures carried out by Primary health care must meet standard procedures including: referring, receiving referrals, returning referrals, receiving reciprocal referrals, managing patients in an ambulance, and referral of special cases. The completeness of facilities and infrastructure at the Puskesmas will also influence doctors in providing referrals to patients(9).

In several cases in the Primary health care, there were patients who did not come directly to the Primary health care to get a referral, so only the patient's family explained the patient's medical condition to the puskesmas medical staff and asked for a referral for the patient. The real condition of patients who do not come directly to the Primary health care cannot be monitored or checked first by the puskesmas medical personnel. Based on in-depth interviews with Health care referral 
officers regarding patients who did not come directly to the puskesmas, the Primary health care asked in advance why the patient did not come and asked the patient to come alone if the reason for the patient's medical condition was still possible to come and be examined first at the Primary health care. However, if the reason that the patient does not come to the Primary health care in person is really due to the patient's medical condition which makes it impossible to come directly to the Primary health care, then the exception is that the puskesmas can provide a referral. However, in some cases, such as an extension of the referral letter, it is usually the patient's family who asks for a referral letter to the Primary health care without being accompanied by the patient who will be referred due to the patient's medical condition.

$\underline{\text { Referral Clinical Procedures }}$

The implementation of the referral system at the Primary health care in Kendari City and Bau-Bau City in clinical procedures is in accordance with the National Referral System Guidelines, the procedure has followed a predetermined routine procedure. Based on the research conducted(10)states that the referral system implementation mechanism will be implemented through an initial examination by the puskesmas doctor if the patient has met one of the criteria for a patient who can be referred and cannot be handled by the puskesmas, then a referral is necessary. If a case is found that cannot be handled according to the doctor's authority, the patient is immediately sent to a health service unit that has the ability to overcome the problem, namely a hospital.(10).

Based on the results of observations and interviews, it is known that several Puskesmas do not yet have SOPs regarding referral of nonemergency cases. Based on in-depth interviews, it was found that the Puskesmas had SOPs regarding the stabilization of the condition of emergency patients to be referred, this stabilization was carried out on patients who came in an emergency situation and were given emergency assistance according to the procedure. Based on the results of interviews with health center referral officers, it was concluded that the patient met the requirements for referral. Preparation of referral patients based on the results of direct observation in the service, it is known that the Primary health care has provided clear explanations to patients / families regarding the referrals to be given to patients, but did not provide informed consent forms to patients.

The Primary health care has not yet contacted the referral destination health facility service unit whether the patient can be accepted at the referral destination health facility when referring a patient, based on the results of the interview, this is because the number of patients referred is large so they do not have time to contact the referral hospital for each patient to be referred. Research conducted(11) It is known that the Tambakrejo and Tanah Kali Kedinding Surabaya Primary health care before making a referral for childbirth contact the destination hospital first, and submit the case to be referred to ensure the availability of a place at the hospital.

Effective referral requires communication between facilities, the goal is that the referred facility knows the patient's condition and can prepare early on the care the patient needs as soon as the patient arrives at the hospital.(11). However, for certain hospitals the Primary health care register online first so that patients get a queue number without needing to come to pick up a queue number. Before the JKN era, not all cases to be referred were confirmed in the Regional Unit Hospital, 
but in the JKN era, with the increasingly stringent regulations regarding referral indications, communication before referring patients was intensified to maintain continuity of service as expected in JKN.(12).

Referral Administrative Procedures

Administrative procedures for referral of Primary health care in Kendari City and Kota Bau-bau have been carried out in line with technical procedures for patients. Based on the results of direct observation at the Puskesmas, it is known that the Primary health care has completed the medical records of the patients to be referred and stabilization measures, completeness in the form of patient diagnosis, diagnosis code, and Poli and Hospital to be referred for referral. Based on the results of in-depth interviews, it is known that there is no informed consent sheet given to patients at the Primary health care to sign the consent, so there is no informed consent in the medical records of the referred patient. The informed consent format is one of the documents that must be included in recording the medical records of the referral patient concerned(5).

Recording and reporting of the referral system must be done properly in order to evaluate the operation of the referral system(12). Based on the results of direct observation, it is known that the health center has recorded patient referrals in the patient referral register which is filled in regularly every day and the administration of patient delivery has been completed when the patient will be referred immediately.

Referral sheets are not printed in duplicate, but patient data has been recorded in the patient's medical record which includes ICD-X code data, diagnosis and destination health facilities and data has been entered in SIMPUS and recorded in the referral register book, as well as in P-Care for
JKN patients . This recording can be used as recording data and reporting of referred patients. However, if there is negligence in recording patient referral data, it will result in invalid and incomplete recording and reporting of referrals.

2. Regionalization System

From the results of the study, that each Primary health care has implemented SOPs based on the regionalization system made by the health department. The regionalization system in question is a referral flow arrangement that adapts to the availability of advanced health facilities within the scope of the area, which is designed to make it easier for the community to reach health facilities.

Based on the results of the research we have done, there are several obstacles in implementing the health referral system in Kendari City and BauBau City, namely the limited ability of health workers to handle emergencies due to limited facilities and infrastructure as well as medicines, limitations of modern transportation facilities and delays in collection. decisions by the family. To overcome this, a regionalization development of health service facilities, both Primary health care and transportation facilities, was made, so as to speed up handling and save on transportation costs.

Regionalization in Bau-Bau City, especially in the Bungi Community Health Center was developed due to limited health service facilities with adequate facilities, limited human resources (HR) who can handle emergency cases and make the referral system closer to communities in remote areas. This is due to the geographical conditions of Bungi District which is a mountainous area, as well as the distance and road infrastructure that does not support reaching health service facilities quickly, especially to the Bau-Bau City 
Hospital which is quite far from Bungi District. This regionalization is intended to make it easier for people to access health service facilities, especially those who live in remote areas.

3. Application

From the research, that in carrying out the health referral process for administrative staff in each Primary health care using the health insurance online-based HFIS application, the application is managed by the Pcare officer of each Heatlh care and monitored directly by BPJS as the application provider. With this application, the patient referral process is easier and faster to do and easier to evaluate because it is data-based.

Social Security Administering Bodies are legal entities established to administer social security programs. Social Security is a form of social protection to ensure that all people can fulfill their basic needs for a decent life. Health insurance participants must first get a referral if they want to get service at the intended hospital. Previously, the references used were tiered. Health insurance participants must get referrals from first-level services to get secondlevel services and so on.

Efforts to speed up and simplify the collaboration process between Health insurance and Health Facilities is by providing the Health Facilies Informaon System (HFIS) application, this HFIS application is an application that can be used by all potential health facilities that will collaborate with Health insurance. This HFI application is an application based on a website that can be used via the public internet by all health facilities candidates who will collaborate with BPJS Kesehatan on the Health insurance website www.bpjs-kkes.go.id.

HFIS is an acronym for Health Facilities Information System, which is a site-based application for monitoring and reporting health facilities profiling data.
The data listed in the HFIS includes the address of health facilities, the person in charge, the number of doctors and other health workers, hours of practice, medical technology, and others. For health facilities, the Health Facilities Information System (HFIS) application can speed up and simplify the collaboration process with BPJS Kesehatan. Through this application, BPJS partners can apply for an extension of cooperation while monitoring and reporting on any developments that occur in these health facilities, including the availability of rooms for BPJS patients.

In terms of service, HFIS will make it easier for officers at first-level health facilities (FKTP) to refer patients to advanced referral health facilities (FKRTL). Officers can easily find the nearest FKRTL, there are not too many queues, and most importantly have the health services needed by patients. Meanwhile, for patients, HFIS which is connected to the 'Applications' service can provide transparency of room availability for BPJS participants. The availability of inpatient rooms is itself one of the most complaints made by BPJS users.

At the first level of health services, Health BPJS strengthens the first tier health facility network by building a Primary Care (P-Care) application. PCare is a patient service information system for Health insurance participants, computer-based and online via the internet. Basically, P-Care has 2 major functions, namely registration by registration officers and patient services where data entry is carried out by doctors or treatment center officers, in which there is also a referral creation feature where the data can be read directly at the referral health facility.(13).

In reducing the number of inappropriate referrals, it is necessary to make appropriate and effective decisionmaking procedures in implementing 
referrals, where by using P-Care it is hoped that the Primary health care can screen for referrals that are not in accordance with the stages of problem identification, relevant data collection, alternative development, alternative evaluation. and selection of the best alternative. Decision making involves a continuous reciprocal action in dealing with a problem. With this appropriate and effective referral decision making, the referral rate will decrease so that it will restore the function of the Primary health care as a gatekeeper and reduce the accumulation of patients in the hospital.

4. Compliance with Rules

From the results of the research, that all Primary health care run a referral system as much as possible based on the existing referral guidelines, but in certain cases that are actually included in 144 diseases that must be completed at the Primary health care level but because the facilities are not available at the Primary health care, health workers are forced to refer not based on from the referral guidelines set by the BPJS. This is because there is a regulation from Health insurance which requires 144 types of diseases to be completed at the Primary health care level, so that the referral option for these 144 types of diseases is not available in the HFIS application.

Increased access to health services since the existence of JKN has not been accompanied by improvements in the service system, especially in referral services. The application of a tiered referral system is actually aimed at controlling the quality of service to make it more optimal. However, the implementation was not as expected. In the tiered referral system, the role of the FKTP is very vital. FKTP is the first health facility to provide services, before being referred to in stages. As a result, the number of patients has increased. This increase was not matched by an increase in services at the FKTP, because the infrastructure was still limited

However, the completeness of the referral letter is still problematic. Although all referral letters are filled in, many are not filled. This resulted in incomplete data and information received at FKTL. In fact, this data and information is needed by health workers at FKTL to take medical action appropriately and accurately.

The most crucial data such as the results of the diagnosis, physical examination, history taking, and therapy that have been given are the information that should be filled in the referral letter. However, most of the data and information are not filled in. The absence of such data causes health workers at the FKTL to not get accurate information to take action on patients.

In some cases of chronic diseases of the return referral program, such as asthma and hypertension, primary care doctors are of the opinion that there are still some specialists who do not want to refer patients back. As a result, FKTP doctors had to write monthly referrals to the hospital so that patients could get medicine because there were drugs that were not available in the FKTP. The behavior of specialists who kept patients in the hospital caused the process in the referral system to not go well. This may be due to the perception of specialist doctors who consider primary care doctors to be less competent in dealing with return referral program diseases. This also causes doctors in puskesmas to run a health referral system that is not in accordance with the rules because it should be in the process of returning a referral,

It must be admitted, the tiered referral system has not run optimally. In terms of management procedures, this system is good. However, the implementation is still problematic. Therefore, improvements need to be 
made at the FKTP. The high rate of patient visits at the FKTP must be balanced with improvements in human resources and service infrastructure. The government needs to improve human resources and infrastructure in the FKTP. These improvements are not only in quantity but also in quality. So that the service can be better and the level of community satisfaction is high

\section{Referral Procedure}

1. Referral Mechanism

Based on the results of the study, it can be obtained that the procedure flow for referring patients is as follows: (1) Registered patients, (2) examined by nurses, (3) entered into polyclinic, (4) referrals are directed to advanced health facilities according to levels. With regards to control patients, in this case the patient is referred back from the hospital, the patient must follow the procedure from the start, namely the list to the examination in the poly and cannot just take a referral.

Referral is the transfer of responsibility from one health service to another. The referral system is a health service network that allows the reciprocal assignment of responsibility for the emergence of problems from a case or public health problem both vertically and horizontally to those who are more competent, affordable and carried out rationally. The referral system is organized with the aim of providing quality health services, so that service objectives are achieved without having to use expensive costs. Referral is a system in which coordination is the main element that is multi-sector in nature and there must be support from various multi-disciplinary and multi-professional professions to carry out and organize an integrated form of service for emergency patients both in everyday situations and in situations of disasters and events. extraordinary. Effective referral requires communication between facilities, the goal is that the referred facility knows the patient's condition and can prepare early on the care the patient needs as soon as the patient arrives at the hospital.(9).

The Primary health care may refer patients to a higher level of health care provided that the patient requires specialized / subspecialistic health services. Referrers can provide health services according to patient needs due to limited facilities, equipment and manpower. Patients outside these criteria should not be referred to a higher level of health care.

The informant stated that the implementation started from the registration counter, then the patient chose the part they wanted, then the patient would be examined by a doctor which included a physical examination, diagnosis and therapy, if this was not possible at the Primary health care then they would be referred to a type $\mathrm{C}$ hospital, from type $\mathrm{C}$, if you can't afford it, you will be referred to a type B hospital, and from type B if you can't, you will be referred to a type A hospital. However, in the referral procedure there are often various kinds of problems, one of which is the problem with the internet which likes errors, This resulted in the primarycare ( $p$-care) application being difficult to open, coupled with the pile of patients queuing up, so doctors would usually provide a manual referral letter.

Regulation of the Minister of Health of the Republic of Indonesia Number 1 of 2012 concerning Individual Health Service Referral Systems explains that the referral system is a health service delivery that regulates the assignment and responsibility of health services both vertically and horizontally. Health services are implemented in stages, according to medical needs starting from the first level of health services. The referral system is compulsory for patients who are participants of health insurance 
or social health insurance and health service providers(5).

The referral system regulates the flow from where and where to go for a person with certain health problems to have their health checked(14). The referral system means that it aims to run effectively and efficiently, which means reduced waiting time in the referral process and less unnecessary referrals because they can actually be handled at the FKTP. The era of the National Health Insurance applies a tiered referral system, where health services begin at the first level health facilities(13). The implementation of a tiered referral system requires BPJS patients to prioritize treatment at a health center, which is a primary service facility. If a patient cannot be treated in a primary care facility, then the patient will be referred to a secondary service facility (ex: hospital).

A vertical referral from a higher level of service to a lower level of service can be done if the patient's health problems can be handled by a lower level of health care according to their competence and authority, the competence and authority of the first or second level of service is better in handling the patient. patients need further services that can be handled by lower levels of health care and for reasons of convenience, efficiency and long-term service and / or referrers cannot provide health services according to patient needs due to limited facilities, infrastructure, equipment and / or personnel (Article 10)(5). The implementation of vertical referrals from higher service levels to return to services at the Puskesmas Kota Kendari and Kota Bau-Bau has also been carried out in accordance with statutory regulations. Based on the results of indepth interviews with referral officers, it is known that patients who are referred back from a higher health service facility to return to the health center for treatment are carried out if the patient feels that his health condition is controlled by the hospital doctor, so that the patient's treatment is returned to the puskesmas.

In providing referrals, puskesmas officers also make cover letters that are handed over to patients. The cover letter for patient referral must at least contain the patient's identity, the results of the examination (history, physical examination and supporting examinations) that have been carried out, work diagnosis, therapy / actions that have been given, the purpose of the referral, the name and signature of the health worker providing the service. (Article 15)(5). Referral cover letters provided by the Primary health care Kendari city and Kota Bau-Bau are in accordance with the referral line which is systemized automatically in Primary Care, namely in the form of an official referral letter from Health BPJS.

2. Initial Action Before Referring

From the results of the study, that before the patient was referred, the health worker at the Primary health care had first taken the patient's initial action, namely by examining, then providing therapy, and if there was still no change in the patient's health status, then the new patient would be referred to the facility. advanced health care providers who are considered more capable of dealing with patient health problems.

Every health care provider is obliged to refer patients when a disease condition or health problem requires it, except for the reason that the patient cannot be transported for medical, resource or geographic reasons and has the consent of the patient or his family. To make a referral, it is necessary to attach an explanation such as: diagnosis and therapy and / or medical action required, reason and purpose for the referral, risks that can arise if the referral is not made, referral transportation, and 
risks or complications that may arise during the trip. According to the Regulation of the Minister of Health of the Republic of Indonesia Number 001 of 2012, before making a referral, it is necessary to take the following actions:

1) Perform first aid and / or stabilization of the patient's condition according to medical indications and in accordance with the ability for patient safety purposes during the referral.

2)Communicating with referral recipients and ensuring that referral recipients can receive patients in the event of an emergency patient.

3) Create a referral cover letter to be submitted to the referral recipient. The cover letter for the reference should at least contain: patient's identity, results of examinations (history, physical examination and supporting examinations) that have been carried out, work diagnosis, therapy and / or actions that have been given, the purpose of the referral, and the name and signature of the health worker. give service.

Referral is a series of activities in response to the inability of a health service center or health facility to carry out medical action against patients. The referral system is a mechanism for transferring or transferring patients that occur within or between health facilities that are in a network. Referral in a broader sense, can be started from the community level to the tertiary health service level and vice versa ("two-way referral") as well as inter-institutional referrals within the health facility. The results referred from the referral system can be the patient himself or other supporting services(5).

The current condition in the Primary health care which is the object of research, referral cases to secondary health services for cases that should be able to be completed in primary care is still quite high. Based on the 2007 and 2010 Basic Health Research (Riskesdas), most of the diseases with the most cases in Indonesia are included in criterion $4 \mathrm{a}$ (doctors are able to diagnose the disease properly and are able to manage properly and correctly) by emphasizing ability level 4 (doctors have the ability to completed 144 disease diagnoses in puskesmas). If the patient has complications, severity of illness, other difficult chronic diseases and patients with decreased immunity, all of which require further treatment,

Based on the Primary health care Standard book (2013), it is stated that emergency services are important services and must be available at the Primary health care so that some Puskesmas that do not yet have emergency services are important to increase their resources so that they can provide emergency services according to community needs.

Based on the JKN Socialization Handbook, it is also explained that emergency services are mandatory services that must be available in health facilities including Primary health care to provide first care for patients and then if the Primary health care is unable to serve, referrals can be made. Therefore it is important to have an emergency room in every Puskesmas, because a Primary health care that has emergency services can provide assistance needs to patients so that patients do not need referral services to hospitals when they need service quickly while Primary health care that do not have emergency services when there are patients in critical condition, referrals will be carried out immediately without going through prior treatment so that it is possible to make higher referrals to the hospital.

Based on the research results obtained by the researcher, for the referral flow, namely starting from the patient arriving then registering and 
being examined by the doctor, then doing anamnesa, physical examination and medic supporting examinations, then determining the patient's diagnosis. If the patient comes in an emergency situation and requires emergency medical assistance, the officer immediately performs immediate help (life saving procedure) to stabilize the patient's condition. After being diagnosed, if indeed the patient's condition requires the patient to be referred and has met the existing referral requirements, the patient will be referred to get the treatment needed.

Whereas for referral administrative procedures at the Primary health care, namely after stabilizing the condition of the pre-referral patient, the officer completes the patient's medical record, the informed consent format is stored in the patient's medical record, then records and reports are carried out in the patient referral register book. Administration of patient dispatch must be completed immediately when the patient is to be referred immediately.

The results of the research obtained by researchers with the guidelines for the national referral system have conformity, namely the requirements for referring patients are the patients who will be referred are examined first, and then it is concluded that the patient's condition is feasible and meets one of the requirements to be referred, then a referral will be made. The referral clinical and administrative procedures carried out in the sample Primary health care were carried out jointly and were in accordance with the referral clinical and administrative procedures in the national referral system guidelines.

Referral must obtain the consent of the patient and / or his family, and the authorized health worker must provide an explanation to the patient regarding the diagnosis and therapy or medical action required by the patient, the reasons and purpose for the referral, the risks that can arise if the referral is not made, referral transportation, and the risks or complications that may arise during the trip (Article 12)(5). The Primary health care Kendari city and Bau-bau city have also explained to patients or their families about the patient's medical condition, the actions needed, the reasons and goals for the referral, and the risks if the referral was not made. The explanation regarding referral transportation is explained in general about the public transportation that the patient can use to get to the referral place. The explanation by the Primary health care is in a language that the patient or the patient's family can understand, usually in Indonesian or local languages.

\section{Reference Pattern}

1. Own Request

From the results of the study, that there are always patients who take the choice of health services, because they are already accustomed to the old system that allows choosing a referral place, or want to choose a referral place that is closer to where the patient lives, there are also patients who do not believe in the facilities and capabilities of the Primary health care thus asking for referrals to other, more reliable facilities.

There are many reasons patients ask to be referred, both for outpatient and hospitalization. A patient or patient's family chooses a referral hospital based on recommendations from lower health facilities, or by location, based on the completeness of health facilities, based on service costs, or based on the patient's severity level.

At the Lepo-lepo Public Health Center Kendari City and the Bukit Wolio Indah Health Center, Bau-Bau City, there are still many patients who ask to be referred for various reasons, 
including suggestions from patients who trust the competence of specialist doctors even though the disease is only minor ailments that can be handled at the FKTP. Lack of trust of patients with the competence of Health care doctors in providing health services both in terms of doctors, examinations carried out and drugs given, characteristics of people in urban environments who are smart, idealistic, and include the upper middle class so that patients underestimate the ability of doctors, patient habits for control to certain specialists, patients who have been treated but without success, and the patient's level of insight about a disease is low.

The referral system is organized with the aim of providing quality, effective and efficient health services, so that the goal of health services is achieved without the use of expensive costs. However, if the referral system in Indonesia does not operate in accordance with existing regulations it will have a negative impact on the government, society and health service providers, namely an increase in the cost of claims in secondary service facilities and an increase in the workload of officers in secondary health care facilities due to their duties and responsibilities. officers in primary health facilities that should be able to be resolved are borne by officers in secondary service facilities.

The implementation of referrals that occurs in the field shows that some referrals occur at the request of the patient, the patient also determines the provision of referrals(14). However, it is not uncommon for the Puskesmas to have patients who insist on asking for referral even though their health condition does not require a referral, so it is not uncommon for doctors and referral officers to argue with patients who ask for referrals at their own request. Research conducted(15)
Patients demanded a referral because they lacked confidence in health services at the first level of health facilities, so even though it was repeatedly explained that the disease could be treated at the Primary health care, they insisted on asking for a referral by threatening to leave the Primary health care.

Based on the results of the FGD with patients at Primary health care Abeli and Primary health care Lepolepo, the reason they asked for a referral letter was because the facilities they needed at the Primary health care were not available, such as inpatient treatment for heart disease, eye pain, ENT. There were also those who argued that the services at the Primary health care were less pleasant for them because the staff were less friendly, less communicative, some felt less trust in the services at the puskesmas and had more confidence in the services at the hospital.

According to the researchers, the results of this study indicate that patient knowledge has a significant effect on referrals to advanced health facilities at Pancur Batu Health Center. Patients who have good knowledge of referral will tend to choose to be referred if they suffer from illness that cannot be treated at the Primary health care. But if the disease can be handled at the Health care, he prefers to seek treatment at the Primary health care. The level of knowledge of the respondents is also related to their level of education. Education is a factor that indirectly influences the mindset, understanding, and knowledge so that it will also affect families in using the puskesmas.

The choice of using referrals or not using referrals to advanced health facilities is a tangible form related to the knowledge held by patients at the Primary health care. Based on the FGD in this study, there are still respondents who think that patients can directly refer to themselves if they feel they are not 
suitable for services at the Puskesmas. The truth is that patients are not allowed to determine the place of referral themselves, and it must be based on the doctor's consideration as well as the condition of the equipment at the health center whether it is suitable for the disease they are suffering from.

According to Alawi, the distance factor plays a very important role in the utilization of health services. In terms of the high number of referral nonspecialized cases in Sukabumi District, it could be caused by the proximity of the Primary health care to the referral facility so that patients prefer to take advantage of health services at referral facilities that are closer to where they live. This can be seen in patients at the Primary health care Lepo-lepo, Kendari City who choose to be referred to a Provincial Hospital which is located very close to the Primary health care, compared to being referred to a City Hospital which is located further away. The same thing happened to the patients of the Bukit Wolio Indah Community Health Center, whose place of residence was closer to the city hospital than the location of the Primary health care.

According to the researcher, based on the results of this study it is evident that the availability of infrastructure affects the referral of Health insurance user patients to advanced health facilities. The more complete infrastructure at the referral site is one of the reasons patients were referred to the FKTL. In general, Health insurance users feel happier if they get treatment at the hospital (advanced health facilities) even though the disease can still be handled at the Puskesmas. This is due to the fact that the facilities at advanced health facilities are more complete than those at the Primary health care. Incomplete facilities and infrastructure at the Puskesmas, for example for patients with eye disease, cannot be carried out more intensive examinations at the Puskesmas and only at advanced health facilities. Likewise with other diseases, heart disease, kidney problems, and others. Apart from equipment, the medicines available at the Primary health care are also considered to be not good enough, because the community often experiences confusion, patients with different types of diseases receive the same types of drugs.

Based on the results of the FGD, many patients have never received information about referral service procedures and the flow of referral implementation. As determined by the Health insurance, it is known that referral service procedures must be in accordance with the referral implementation flow so as not to cause high referral rates at primary health services and also do not experience a buildup of health services at the secondary level, namely hospitals. The lack of information received by patients about what diseases can be referred causes patients to prefer to go to secondary level services due to the low level of patient confidence in seeking treatment at primary health services.(16).

According to researchers, the results of this study indicate that health information affects the referral of Health insurance users to advanced health facilities. This is because correct and accurate information will make Health BPJS user patients better understand the tiered referral flow at puskesmas to advanced health facilities. But in fact, some respondents stated that they did not get adequate information about referrals and the right referral path. Information about Health insurance patient referral flow is important for all Health BPJS users to know so that they do not ask for referrals and places for referrals based on the patient's wishes but are determined by the Primary health 
care or hospital or the provisions of the Health insurance itself.

2. Attitude

From the results of the study, that for patients who are not eligible for referral, the health worker will be given education first, if they continue to insist, the requested referral will not be given by the doctor and allowed directly to advanced health facilities without being given a letter. referral, then automatically all medical expenses will not be borne by Health insurance, in the sense that the patient uses personal funds when checking himself in at an advanced health facility.

One of the obstacles for doctors not being able to handle the disease completely is the factor in the patient's request to be referred to the hospital without medical indication. The tendency of patients to be referred is usually done by patients who participate in ex-Askes. Doctors have explained to patients that the disease can be handled by primary care doctors, but some still want to get health services at the hospital.

Most of the patients who asked for referral had been given an explanation beforehand by the doctor. From the explanation given by the doctor to the patient who asked to be referred, there were patients who understood but some still asked to be referred. For patients who still ask to be referred, there are doctors who will remain in their stance not to provide referrals and advise patients to directly visit the FKRTL without a referral letter, but in some cases, doctors end up referring the patient because the doctor is reluctant to argue with the patient even though in fact, despite the service health is the right of the patient, but the one who is authorized to provide a referral is still a doctor.

The basic process of decision making includes identifying and diagnosing problems, namely identifying (identifying) and determining (defining) the problem, collecting relevant data, namely determining what data will be needed to make the right decisions and then obtaining this information, developing alternatives, namely finding solutions. potential for these problems in order to obtain information so that it can be developed into possible alternatives, alternative evaluation, namely evaluating to assess the effectiveness of each alternative by looking at the positive and negative impacts, selecting the best alternative, namely solving problems in order to achieve previously planned goals,implementation of decisions, namely testing decisions by looking at the behavior of people who are affected by that decision as well as control and evaluation, namely change, if necessary, the solution chosen is made at the time of implementation, or if the initial goal is deemed not achieved.

The best alternative that is mostly chosen by health workers at the Health care is education and motivation where education and motivation are given to provide knowledge to the community about referrals. This is in accordance with research which states that the various wishes of Health insurance patients when asking for referrals to puskesmas doctors start from their own wishes, for fun and there are also referrals given on the advice of doctors. The patient's request for a referral is a very big influence when a doctor makes a decision to make a referral. The high desire of the patient in making referrals, the best solution given in this study is education and motivation where education and motivation are given in order to provide knowledge to the public about referrals.

Therefore, it can be concluded that Health care should follow up in reducing the referral rate in the form of outreach to cross-sectors and the community 
regarding the availability of human resources in the form of doctors and medical personnel as well as available medicines needed by the community. It is hoped that the Primary health care will not only disseminate information to the community but also provide quality human resources, facilities and infrastructure as well as medicines for the community so that patients are served at the Primary health care without having to be referred.

\section{CONCLUSION}

There is a conceptual linkage between the Reference Guidelines, Referral Procedures, and Reference Patterns with the concept of implementing the referral system. So thatthe need for coordination to build an integrated health center information system between Pcare and Simpus (Primary health care Information System), especially to include information on reasons for referrals in patient databases. This information will later become the basis for assessing reference figures that can be used as a reference in calculating capitation based on fulfilling commitments

\section{REFERENCES}

1. Health WHODoM, Abuse S, Organization WH, Health WHODoM, Health SAM, Evidence WHOMH, et al. Mental health atlas 2005: World Health Organization; 2005.

2. Akbar MI. Studi Implementasi Program Jaminan Kesehatan Nasional Di Kabupaten Muna. Jurnal Kesehatan Masyarakat Celebes. 2020;1(03):21 77.

3. Rumengan DS, Umboh J, Kandou G. Faktor-faktor yang berhubungan dengan pemanfaatan pelayanan kesehatan pada peserta BPJS kesehatan di Puskesmas Paniki Bawah Kecamatan Mapanget Kota Manado. Jikmu. 2015;5(2).
4. Peraturan Presiden Republik Indonesia nomor 12 tahun 2013 Tentang Jaminan Kesehatan, (2013).

5. KemenKes R. Profil data kesehatan Indonesia tahun 2011. Jakarta: Kementerian Kesehatan Republik Indonesia. 2012.

6. BPJS Kesehatan Cabang Kendari. Laporan BPJS Kesehatan Kota Kendari. Sulawesi Tenggara2019.

7. Anhar A, Ismail CS. Studi Komparatif Pemanfaatan Pelayanan Kesehatan pada Masyarakat Pedesaan di Wilayah Kerja Puskesmas Poleang Barat dengan Masyarakat Perkotaan di Wilayah Kerja Puskesmas Lepo-lepo Tahun 2015. Jurnal Ilmiah Mahasiswa Kesehatan Masyarakat. 2016;1(2).

8. Doaly G, Kandou GD, Abeng TD. Analisis Pelaksanaan Sistem Rujukan Pasien di Rumah Sakit Umum Daerah (RSUD) Dr. Sam Ratulangi Tondano Kabupaten Minahasa. Community Health. 2018;2(5).

9. Ratnasari D. Analisis Pelaksanaan Sistem Rujukan Berjenjang Bagi Peserta JKN di Puskesmas X Kota Surabaya. Jurnal Administrasi Kesehatan Indonesia. 2017;5(2):14554.

10. Susilowati Amrullah P. Asuhan Keperawatan Pada Pasien Dengan Gangguan Kebutuhan Oksigenasi Akibat Patologi Sistem Pernapasan: Tb Paru Di RSUD Wakatobi: Jurusan Keperawatan; 2019.

11. Rukmini R. Pelaksanaan Sistem Rujukan Maternal di Puskesmas Tambakrejo dan Tanah Kali Kedinding Kota Surabaya. Buletin Penelitian Sistem Kesehatan. 2015;18(4):365-75.

12. Primasari KL. Analisis Sistem Rujukan Jaminan Kesehatan Nasional RSUD. Dr. Adjidarmo Kabupaten Lebak. Jurnal Administrasi Rumah Sakit Indonesia. 2015;1(2).

13. BPJS Kesehatan. Panduan Praktis Sistem Rujukan Berjenjang. Jakarta: Indonesia; 2014. 
Risky, S., Harun, A. A., \& Depu, A. H.

DOI: 10.36566/ijhsrd/Vol3.Iss1/79

https://ijhsrd.com/index.php/ijhsrd

14. Hamzah N. Rujukan berjenjang dalam pelayanan rumah sakit ditinjau dari segi hukum. Jurnal Hukum Bisnis. 2020;4(1):376-87.

15. Goniwala G. Gambaran Pelaksanaan Rujukan Peserta BPJS Kesehatan di Puskesmas Tikala Baru dan Puskesmas Teling Atas di Kota Manado. Manado: Universitas Sam Ratulangi. 2017.

16. Sihombing IN. Analisis Pelaksanaan Program Rujuk Balik (Studi Kasus Pelaksanaan Program Rujuk Balik Pada Program Jaminan Kesehatan Nasional di Puskesmas Pancur Batu Kabupaten Deli Serdang Tahun 2017. 2018. 